\title{
ANALISIS PENENTUAN MUSIM PENANGKAPAN \\ IKAN CAKALANG (Katsuwonus pelamis L.) \\ DI PERAIRAN BELANG MINAHASA TENGGARA-SULAWESI UTARA
}

\author{
John Socrates Kekenusa ${ }^{1)}$, Marline S. Paendong ${ }^{1)}$ \\ ${ }^{1)}$ Staf Pengajar Jurusan Matematika/Statistika f-mipa unsrat \\ e-mail: johnskekenusa@yahoo.com; marline_paendong@yahoo.com
}

\begin{abstract}
ABSTRAK
Studi pada musim penangkapan untuk ikan cakalang (Katsuwonus pelamis), digambarkan di perairan Belang, Minahasa Tenggara - Sulawesi Utara. Data yang digunakan berdasarkan hasil tangkapan dan memancing bulanan oleh pukat cincin di tempat pendaratan ikan di Belang selama tahun 2009 sampai 2015. Analisis untuk musim memancing menggunakan Metode Persentase rata. Hasil penelitian menunjukkan bahwa ikan cakalang dapat ditangkap sepanjang tahun. Musim penangkapan ikan untuk cakalang terjadi selama Maret, April, Juni, Agustus, September, dan Oktober sementara bulan lainnya bukan musim memancing.
\end{abstract}

Kata kunci: ikan cakalang, pukat cincin, musim penangkapan ikan, Metode Persentase rata.

\section{ANALYSIS DETERMINATION OF FISHING SEASON SKIPJACK TUNA (Katsuwonus pelamis L.) IN THE BELANG WATERS OF SOUTHEAST MINAHASA NORTH SULAWESI}

\begin{abstract}
Study on fishing season for skipjack tuna Katsuwonus pelamis, was described in the Belang waters, South East Minahasa - North Sulawesi. The data was used based upon the catch and fishing trip monthly by purse seine in fish landing places at Belang over the periods 2009 to 2015 . The analysis for fishing season using The Average Percentage Methods.

The result showed that the skipjack tuna can be caught throughout the year. The fishing season for skipjack tuna occurred during March, April, June, August, September, and October while other months are not fishing season.
\end{abstract}

Keywords: Skipjack tuna, purse seine, fishing season, The Average Percentage Methods.

\section{PENDAHULUAN}

Ikan cakalang (Katsuwonus pelamis L.) tergolong sumberdaya perikanan pelagis penting dan merupakan salah satu komoditi ekspor nir-migas. Ikan cakalang terdapat hampir di seluruh perairan Indonesia, terutama di Bagian Timur Indonesia.

Perairan Belang dan sekitarnya, merupakan salah satu pusat kegiatan penangkapan cakalang di Sulawesi Utara. Hasil tangkapan cakalang di Sulawesi Utara (termasuk yang tertangkap di perairan Belang) untuk tahun 2010 mencapai 60.190,3 ton dengan nilai ratusan milyar rupiah (DKP Provinsi Sulawesi Utara, 2011).

Kegiatan penangkapan ikan tuna termasuk cakalang telah berkembang di perairan Indonesia, khususnya perairan timur Indonesia sejak awal tahun 1970-an (Wild dan Himpton, 1994 dalam Sala, 1999). Penangkapan cakalang di Indonesia dilakukan dengan menggunakan huhate (pole and line), pancing tonda (troll line), pukat cincin (purse seine), jaring insang, dan payang (Burhanuddin, 1984 dalam Tampubolon, 1990).

Peningkatan produksi ikan cakalang di perairan Belang dan sekitarnya, masih dapat ditingkatkan, apabila operasi penangkapannya dapat dilakukan dengan cara yang efektif dan efisien. Salah satu caranya ialah dengan mengetahui musim tangkap ikan, sehingga dapat dilakukan persiapan yang lebih baik untuk melakukan operasi penangkapan yang lebih terarah. 
Tulisan ini membahas mengenai periode musim penangkapan ikan cakalang di perairan Belang dan sekitarnya, berdasarkan hasil tangkapan dan jumlah trip penangkapan per bulan dengan pukat cincin (purse seine) di tempat-tempat pendaratan ikan di Belang, selang waktu tahun $2009-2015$.

\section{METODE PENELITIAN Sumber Data}

Data hasil tangkapan ikan cakalang (ton/bulan) dan upaya tangkap (trip/bulan) bersumber dari beberapa tempat pendaratan ikan di Belang untuk tahun 2009 - 2015.

\section{Metode Analisis Data}

Analisis pola musim penangkapan ikan menggunakan Metode Persentase Ratarata (The Average Percentage Methods) yang didasarkan pada Analisis Runtun Waktu (Times Series Analysis) dari Spiegel (1961). Prosedurnya ialah sebagai berikut (Purwasasmita, 1993):

1. Hitung nilai hasil tangkapan per upaya tangkap (CPUE $=$ Catch Per Unit of Effort $=\mathrm{U})$ per bulan $\left(\mathrm{U}_{\mathrm{i}}\right)$ dan rata-rata bulanan CPUE dalam setahun $(\bar{U})$.

$\bar{U}=\frac{1}{m} \sum_{i=1}^{m} U_{i}$

$\bar{U} \quad=$ CPUE rata-rata bulanan dalam setahun (ton/trip)

$U_{i}=$ CPUE per bulan (ton/trip)

$\mathrm{m}=12$ (jumlah bulan dalam setahun)

2. Hitung $\mathrm{U}_{\mathrm{p}}$ yaitu rasio $\mathrm{U}_{\mathrm{i}}$ terhadap $\bar{U}$ dinyatakan dalam persen :

$U_{p}=\frac{U_{i}}{\bar{U}} \times 100 \%$

3. Selanjutnya dihitung:

$$
\begin{aligned}
& \mathrm{IM}_{\mathrm{i}}=\frac{1}{t} \sum_{i=1}^{t} U_{p} \\
& \mathrm{IM}_{\mathrm{i}}=\text { Indeks Musim ke i } \\
& \mathrm{t}=\text { Jumlah tahun dari data }
\end{aligned}
$$

4. Jika jumlah $\mathrm{IM}_{\mathrm{i}}$ tidak $1200 \%$ (12 bulan $\mathrm{x}$ $100 \%$ ), maka diperlukan penyesuaian dengan rumus (3) sebagai berikut:

$$
\mathrm{IMS}_{\mathrm{i}}=\frac{1200}{\sum_{i=1}^{m} I M_{i}} \times \mathrm{IM}_{\mathrm{i}}
$$

$\mathrm{IMS}_{\mathrm{i}}=$ Indeks Musim ke i yang disesuaikan
5. Jika dalam perhitungan ada nilai ekstrim pada $U_{p}$, maka nilai $U_{p}$ tidak digunakan dalam perhitungan Indeks Musim (IM), yang digunakan ialah median (Md) dari IM tersebut. Jika jumlah nilai Md tidak sebesar $1200 \%$, maka perlu dilakukan penyesuaian sebagai berikut:

$$
\operatorname{IMMdS}_{\mathrm{i}}=\frac{1200}{\sum_{i=1}^{m} M d_{i}} \times \mathrm{Md}_{\mathrm{i}} \quad \ldots \ldots .
$$

$\mathrm{IMMdS}_{\mathrm{i}}=$ Indeks Musim dengan Median yang disesuaikan ke $i$.

6. Kriteria penentuan musim ikan ialah jika indeks musim lebih dari 1 (lebih dari 100 $\%$ ) atau di atas rata-rata, dan bukan musim jika indeks musim kurang dari 1 (kurang dari $100 \%)$. Apabila IM = $1(100 \%)$, nilai ini sama dengan harga rata-rata bulanan sehingga dapat dikatakan dalam keadaan normal atau berimbang.

\section{HASIL DAN PEMBAHASAN}

Data Catch per Unit of Effort (CPUE) bulanan (ton/trip) disajikan pada Lampiran 1. Perhitungan Indeks Musim (IM) penangkapan ikan cakalang dengan menggunakan rumus pada persamaan (1) sampai persamaan (5) seperti pada Lampiran 2, yang secara ringkas disajikan pada Tabel 1. Indeks Musim yang digunakan ialah Indeks Musim dengan Median yang disesuaikan (IMMdS).

Tabel 1. Nilai Indeks Musim (IM) ikan cakalang di Perairan Belang

\begin{tabular}{|l|l|c|}
\hline No & \multicolumn{1}{|c|}{ Bulan } & $\begin{array}{c}\text { Indeks Musim } \\
\text { Disesuaikan (\%) }\end{array}$ \\
\hline 1 & Januari & 98,3 \\
\hline 2 & Februari & 97,9 \\
\hline 3 & Maret & 106,1 \\
\hline 4 & April & 101,6 \\
\hline 5 & Mei & 98,3 \\
\hline 6 & Juni & 106,1 \\
\hline 7 & Juli & 99,3 \\
\hline 8 & Agustus & 101,2 \\
\hline 9 & September & 110,9 \\
\hline 10 & Oktober & 103,2 \\
\hline 11 & November & 90,6 \\
\hline 12 & Desember & 86,4 \\
\hline
\end{tabular}




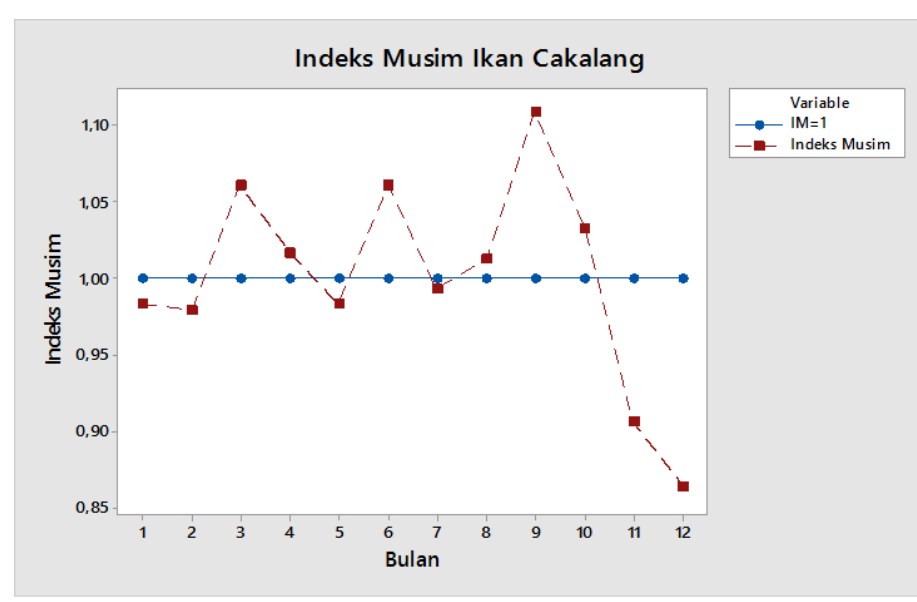

Gambar 1. Indeks pola musim penangkapan ikan cakalang di Perairan Belang

Nilai Indeks Musim terdapat dalam Tabel 1, ditampilkan pada Gambar 1. Nilai IM yang lebih dari $100 \%$ (lebih dari 1) menunjukkan musim tangkap, sedangkan yang kurang dari 100\% (kurang dari 1) bukan sebagai musim tangkap.

Berdasarkan analisis musim penangkapan ikan dengan metode prosentase rata-rata (Lampiran 2 dan Gambar 1), terlihat bahwa ikan cakalang di perairan Belang dapat ditangkap sepanjang tahun dan bervariasi setiap bulan. Bulan Maret, April, Juni, Agustus, September, dan Oktober sebagai musim tangkap, sedangkan bulan lainnya bukan musim tangkap.

Musim tangkap ini, ada yang sama dengan yang dilaporkan oleh Monintja dan Zulkarnain (1995), bahwa musim tangkap cakalang, umumnya terjadi duakali dalam setahun, puncaknya bulan Maret - April dan Oktober - November. Dalam penelitian ini, terungkap bahwa pada bulan Maret, April, September, dan Oktober masih tinggi, tetapi bulan November menurun sampai bulan Desember. Hasil tangkapan tertinggi diperoleh pada bulan September.

Dari penelitian penulis di perairan Bitung terungkap bahwa bulan Februari, Maret, dan April sebagai musim tangkap ikan cakalang (Kekenusa, 2006). Uktolseja $d k k$ (1997) menyatakan bahwa, musim tangkap cakalang di perairan sekitar Bitung dibagi menjadi empat kategori, yaitu : (1). Musim tangkap I bulan April - Juni, dengan puncaknya pada bulan Juni, (2). Musim tangkap II (September - November), puncaknya bulan November, (3). Bukan musim tangkap I (Juli - Mei), paling rendah bulan Mei, dan (4). Bukan musim tangkap II
(Desember - Maret), paling rendah bulan Januari.

Sampai dengan tahun 1990, daerah penangkapan cakalang oleh nelayan di Sulawesi Utara masih di bawah 30 mil dari garis pantai. Tetapi mulai tahun 1991 daerah penangkapan menjadi lebih jauh ke tengah, yaitu sekitar rumpon yang dipasang di wilayah ZEEI, milik perusahaan nasional yang bekerjasama dengan perusahaan asing. Selanjutnya Gafa et al., (1993) menyatakan bahwa faktor-faktor yang mempengaruhi penurunan hasil tangkapan cakalang per unit huhate pada tahun 1992 di Sulawesi Utara ialah akibat: (1). meningkatnya upaya penangkapan oleh perikanan huhate, (2). tekanan penangkapan dengan pukat cincin, dan (3). faktor alam, yaitu naiknya suhu perairan laut mencapai $30{ }^{\circ} \mathrm{C}$ akibat musim kemarau panjang.

Huhate (pole and line) cenderung menangkap ukuran yang lebih kecil dan ukuran kelas yang lebih sedikit dibanding dengan pukat cincin (purse seine). Selektifitas huhate dapat dimodifikasi dengan merubah ukuran pancing, berat tangkai, dan ukuran umpan, tetapi yang paling berarti memilih ukuran dari gerombolan ikan. Selektifitas ukuran pukat cincin dapat divariasikan dengan memilih gerombolan dan mengatur ukuran mata jaring sesuai dengan ukuran ikan yang ditangkap atau lebih besar (Matsumoto et al., 1984)

Pada bulan Desember hasil tangkapan menurun, umumnya disebabkan karena terjadi musim angin barat yang berombak besar sehingga jumlah trip penangkapan berkurang. Perbedaan musim tangkap, bisa saja disebabkan oleh perbedaan jumlah armada penangkapan pada saat penelitian dilakukan. Perbedaan sumber dan akurasi data yang diperoleh, juga dapat menyebabkan hasil yang berbeda.

Dengan didapatkannya informasi musim tangkap ikan, diharapkan para nelayan dapat melakukan penangkapan ikan secara lebih terencana dan efisien. Mereka dapat menangkap secara lebih intensif dan mengatur jumlah armada tangkap pada bulan-bulan musim tangkap. Namun demikian, dalam hal ini diperlukan kebijakan pemerintah melalui Dinas Kelautan dan Perikanan untuk mengatur jumlah armada penangkap ikan yang beroperasi, jangan sampai terjadi tangkap lebih (overfishing). 
Hasil penelitian ini diharapkan merupakan informasi berharga, terutama bagi para nelayan dan pengusaha perikanan cakalang dalam mengelola usahanya secara lebih efisien dalam menentukan waktu tangkap dan jumlah armada. Penelitian ini juga bermanfaat bagi pemerintah melalui Dinas Kelautan dan Perikanan setempat dalam menetapkan perencanaan perikanan cakalang yang efisien dan lestari.

\section{KESIMPULAN DAN SARAN Kesimpulan}

Ikan cakalang di perairan Belang dan sekitarnya dapat ditangkap sepanjang tahun. Musim tangkap ialah pada bulan Maret, April, Juni, Agustus, September, dan Oktober, sedangkan bulan lainnya bukan musim tangkap.

\section{Saran}

Pada musim tangkap perlu dilakukan persiapan yang lebih baik, terutama tentang kondisi kapal agar dapat beroperasi dengan kapasitas penuh. Jika melakukan perbaikan kapal penangkap ikan, sebaiknya pada saat bukan musim tangkap ikan cakalang.

\section{DAFTAR PUSTAKA}

[DKP] Dinas Kelautan dan Perikanan Provinsi Sulawesi Utara. 2012. Statistik Perikanan Tangkap Sulawesi Utara Tahun 2011.

Gafa, B., I.G.S. Merta, H.R. Barus, dan E.M. Amin. 1993. Penurunan Hasil Tangkapan Ikan Tuna dan Cakalang di Perairan Sulawesi Utara dan Faktorfaktor yang Mempengaruhinya. Jur. Pen. Perikanan Laut $72: 11-19$.

Kekenusa, J.S. 2006. Analisis Penentuan Musim Penangkapan Ikan Cakalang (Katsuwonus pelamis, L.) Di Perairan Bitung Sulawesi Utara. Jurnal Protein, Vol. 13 No.1 : 90-97 (Akreditasi Dikti : No.134/DIKTI/Kep/2002).

Kekenusa, J.S. 2012. Analisis Penentuan Musim Penangkapan Ikan Cakalang (Katsuwonus pelamis, L.) Di Perairan Manado, Sulawesi Utara. Penelitian Hibah bersaing.
[LPPM] Lembaga Penelitian dan Pengabdian kepada Masyarakat Universitas Sam Ratulangi. 2015. Panduan Pelaksanaan Penelitian dan Pengabdian kepada Masyarakat (Dana PNBP UNSRAT).

Matsumoto, W.M., R.A. Skillman, and A.E. Dizon. 1984. Synopsis of Biological Data on Skipjack Tuna, Katsuwonus pelamis: NOOA Technical Report NMFS Circular 451. U.S. Department of Commerce. $92 \mathrm{p}$.

Monintja, D. R., dam Zulkarnain. 1995. Analisis Dampak Pengoperasian Rumpon Tipe Philipine di Perairan ZEE terhadap Perikanan Cakalang di Perairan Teritorian Selatan Jawa dan Utara Sulawesi. Laporan Penelitian. Fakultas Perikanan Institut Pertanian Bogor. Bogor. 70 hal.

Paendong, M.S, J.S. Kekenusa, W.Ch. Weku. 2014. Analisis Penentuan Musim Penangkapan Ikan Cakalang (Katsuwonus pelamis L.) di Perairan Sangihe - Sulawesi Utara. Jurnal DeCartesian Vol 3(2):36-41.

Purwasasmita, R. 1993. Musim Penangkapan Ikan Cakalang, Katsuwonus pelamis, dengan Kapal-kapal Huhate dan Pengaruhnya Terhadap Peningkatan Produksi di Perairan Sekitar Sorong. Jur. Pen. Perikanan Laut 79: 1 - 13.

Sala, R. 1999. Perikanan Cakalang di Sorong, Irian Jaya dan Kemungkinan Pengembangannya. Tesis (Tidak Dipublikasikan). Program Pascasarjana Institut Pertanian Bogor. Bogor.

Spiegel, M. R. 1961. Theory and Problems of Statistics. Schaum Publ. Co., New York.

Tampubolon, N. 1990. Studi Tentang Perikanan Cakalang dan Tuna Serta Kemungkinan Pengembangannya di Pelabuhan Ratu, Jawa Barat. Skripsi (Tidak Dipublikasikan). Program Studi Pemanfaatan Sumberdaya Perikanan, Fakultas Perikanan Institut Pertanian Bogor. Bogor.

Uktolseja, J.C.B. 1997. Laporan Penelitian Indeks Kelimpahan Ikan Tuna dan Cakalang di Sekitar Rumpon (Tidak Diterbitkan). Balai Penelitian Perikanan Laut, Jakarta. 
Lampiran 1. Nilai CPUE (ton/trip) bulanan ikan cakalang di Perairan

Belang tahun 2009 - 2015

\begin{tabular}{|c|c|c|c|c|c|c|c|c|c|c|c|c|c|c|c|}
\hline \multirow[t]{2}{*}{ No } & \multirow[t]{2}{*}{ Tahun } & \multicolumn{12}{|c|}{$\begin{array}{c}\mathbf{U}_{\mathbf{i}}=\mathbf{C P U E}(\text { ton per trip) } \\
\text { Bulan : }\end{array}$} & \multirow{2}{*}{$\begin{array}{c}\text { Total } \\
\mathbf{U}_{\mathbf{i}}\end{array}$} & \multirow[b]{2}{*}{$\bar{U}$} \\
\hline & & Jan & Feb & Mar & Apr & Mei & Jun & Jul & Ags & Sep & Okt & Nov & Des & & \\
\hline 1 & 2009 & 1,01 & 1,03 & 1,05 & 1,07 & 1,01 & 1,05 & 1,02 & 1,13 & 1,14 & 1,03 & 0,88 & 0,87 & 12,29 & 1,02 \\
\hline 2 & 2010 & 1,00 & 1,02 & 1,03 & 1,04 & 1,01 & 1,13 & 1,00 & 1,02 & 1,03 & 1,04 & 0,88 & 0,87 & 12,07 & 1,00 \\
\hline 3 & 2011 & 0,84 & 0,85 & 0,92 & 0,86 & 0,88 & 0,89 & 0,84 & 0,84 & 0,86 & 0,86 & 0,75 & 0,73 & 10,12 & 0,84 \\
\hline 4 & 2012 & 1,50 & 1,45 & 2,31 & 0,98 & 1,09 & 1,07 & 2,17 & 2,19 & 1,95 & 2,01 & 2,07 & 1,71 & 20,5 & 1,71 \\
\hline 5 & 2013 & 0,73 & 0,74 & 0,93 & 0,74 & 0,77 & 0,93 & 0,93 & 0,87 & 0,94 & 1,00 & 1,02 & 0,88 & 10,48 & 0,87 \\
\hline 6 & 2014 & 0,75 & 0,68 & 0,69 & 0,73 & 0,70 & 0,78 & 0,79 & 0,73 & 0,84 & 0,56 & 0,63 & 0,47 & 8,35 & 0,69 \\
\hline 7 & 2015 & 1,24 & 1,12 & 1,55 & 1,25 & 1,18 & 1,74 & 1,26 & 1,15 & 1,79 & 1,40 & 1,25 & 1,22 & 16,15 & 1,35 \\
\hline
\end{tabular}

Lampiran 2. Perhitungan pola musim (Indeks Musim) ikan cakalang di Perairan Belang dengan metode prosentase rata-rata

\begin{tabular}{|c|c|c|c|c|c|c|c|c|c|c|c|c|c|c|}
\hline \multirow[b]{2}{*}{ No } & \multirow[b]{2}{*}{ Tahun } & \multicolumn{12}{|c|}{ Bulan : } & \\
\hline & & Jan & Feb & Mar & Apr & Mei & Jun & Jul & Ags & Sep & Okt & Nov & Des & \\
\hline 1 & 2009 & 99,0 & 100,9 & 102,9 & 104,9 & 99,0 & 102,9 & 100,0 & 110,8 & 111,8 & 100,9 & 86,3 & 85,3 & \\
\hline 2 & 2010 & 100,0 & 102,0 & 103,0 & 104,0 & 101,0 & 113,0 & 100,0 & 102,0 & 103,0 & 104,0 & 88,0 & 87,0 & \\
\hline 3 & 2011 & 100,0 & 101,2 & 109,5 & 102,4 & 104,8 & 105,9 & 100,0 & 100,0 & 102,4 & 102,4 & 89,3 & 86,9 & \\
\hline 4 & 2012 & 87,7 & 84,8 & 135,1 & 57,3 & 63,7 & 62,8 & 126,9 & 128,1 & 114,0 & 117,5 & 121,1 & 100,0 & \\
\hline 5 & 2013 & 83,9 & 85,1 & 106,9 & 85,1 & 88,5 & 106,9 & 106,9 & 100,0 & 108,0 & 114,9 & 117,2 & 101,1 & \\
\hline 6 & 2014 & 108,7 & 98,6 & 100,0 & 105,8 & 101,4 & 113,0 & 114,5 & 105,8 & 121,7 & 81,2 & 91,3 & 68,1 & \\
\hline 7 & 2015 & 91,9 & 82,9 & 114,8 & 92,6 & 87,4 & 128,9 & 93,3 & 85,2 & 132,6 & 104,5 & 92,6 & 90,4 & \\
\hline & Total & 671,2 & 655,5 & 772,2 & 652,1 & 645,8 & 733,4 & 741,6 & 731,9 & 793,5 & 725,4 & 685,8 & 618,8 & Total \\
\hline & $\mathbf{I M}_{\mathbf{i}}$ & 95,9 & 93,6 & 110,3 & 93,2 & 92,3 & 104,8 & 105,9 & 104,6 & 113,4 & 103,6 & 97,8 & 88,4 & 1203,8 \\
\hline & $\mathbf{I M S}_{\mathbf{i}}$ & 95,6 & 93,3 & 109,9 & 92,9 & 92,0 & 104,5 & 105,6 & 104,3 & 113,0 & 103,3 & 97,5 & 88,1 & \\
\hline & $\mathbf{M} \mathbf{d}_{\mathbf{i}}$ & 99,0 & 98,6 & 106,9 & 102,4 & 99,0 & 106,9 & 100,0 & 102,0 & 111,8 & 104,0 & 91,3 & 87,0 & 1208,9 \\
\hline & $\mathbf{M d S}_{\mathbf{i}}$ & 98,3 & 97,9 & 106,1 & 101,6 & 98,3 & 106,1 & 99,3 & 101,2 & 110,9 & 103,2 & 90,6 & 86,4 & \\
\hline
\end{tabular}

